$1-1-1964$

\title{
Effect of time of summer pruning on bud set, limb development, and short growth of sheared pines
}

James H. Brown

Follow this and additional works at: https://researchrepository.wvu.edu/ wv_agricultural_and_forestry_experiment_station_bulletins

\section{Digital Commons Citation}

Brown, James H., "Effect of time of summer pruning on bud set, limb development, and short growth of sheared pines" (1964). West Virginia Agricultural and Forestry Experiment Station Bulletins. 498.

https://researchrepository.wvu.edu/wv_agricultural_and_forestry_experiment_station_bulletins/464 @ WVU. It has been accepted for inclusion in West Virginia Agricultural and Forestry Experiment Station Bulletins by an authorized administrator of The Research Repository @WVU. For more information, please contact ian.harmon@mail.wvu.edu. 




\section{THE AUTHOR}

Author of Effect of Time of Summer Pruning on Bud Set, Limb Development, and Shoot Growth of Sheared Pines is James H. Brown, Assistant Silviculturist in the West Virginia University Agricultural Experiment Station.

WEST ViRginia UNIVERSITY Agricultural Experiment Station

College of Agrigulture, forestry, and Home Economics A. H. Vanlandingham, Director MORGANTOWN 


\section{Contents}

INTRODUCTION $\ldots \ldots \ldots \ldots \ldots$

PROCEDURE $\ldots \ldots \ldots \ldots \ldots \ldots \ldots \ldots \ldots$

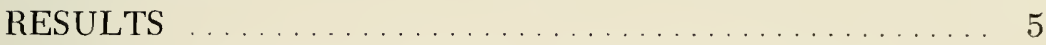

Effect of Time of Pruning on Bud Set and Limb

Development on Cut Stemis. . . ............. 5

Effect of Time of Pruning on Terminal Growth

THE Following Year. . . . . . . . . . . . . . 13

Variations in Bud Set and Shoot Development Caused by Differences in Growing Season and Altitude. . 18

Variation in Bud Set, Limb Formation, and Growth on the Terminal and Different Whorls of Limbs. . 22

Differences in Bud Set and Limb Development After First and Later Prunings. . . . . . . . . . . 24

Needle Length as a Guide to Proper Time to Prune. . . 24 SUMMARY AND CONCLUSIONS . . . . . . . . . . . 27 LITERATURE CITED . . . . . . . . . . . . . . . . . . 30

APPENDIX .............................. 31 
Digitized by the Internet Archive in 2010 with funding from

Lyrasis Members and Sloan Foundation 


\section{Effect of Time of Summer Pruning On Bud Set, Limb Development, And Shoot Growth of Sheared Pines}

\section{Introduction}

James H. Brown

THE number of plantation-grown Christmas trees is increasing yearly. Sowder (1956 and 1961) estimated that in 1955 there were approximately 225,000 acres of privately owned land in the United States planted solely in Christmas trees. In 1960 this estimate had risen to over 625,000 acres. Mitchell and Kendrich (1960) estimated that in Ohio alone total plantings of Christmas trees had risen from slightly over 500,000 trees in 1948 to over 3.2 million in 1956.

With this tremendous increase in production of plantation-grown Christmas trees, it is becoming increasingly important that the grower offer high quality trees for sale to the public. Production of such trees requires a great deal of care and cultural treatment in the plantation. Pruning or shearing, ${ }^{1}$ a cultural practice used to produce a more compact and symmetrical tree, is of primary importance.

Scotch pine (Pinus sylvestris L.), red pine (Pinus resinosa Ait.), and white pine (Pinus strobus L.) make up approximately two-thirds of the total number of Christmas trees planted in West Virginia. After an initial establishment period of one to four years, during which seedlings are developing an extensive root system, trees of these species usually grow so rapidly that long internodes between whorls of limbs and laterals of varying length give them an open and irregular appearance (Figure 1). Without pruning it is probable that only 30 to 40 per cent of the trees will be of salable quality. With proper cultural treatment, principally shearing, the number of salable, high quality trees can be increased to 75 to 90 per cent of the total number planted (Figure 2).

Although pruning requires considerable expenditure of time and money, this expenditure is well justified by the increased value of the crop. Not only will the grower be able to command a better price

${ }^{1}$ In this bulletin the terms shearing and pruning are used interchangeably with no distinction between the two. 


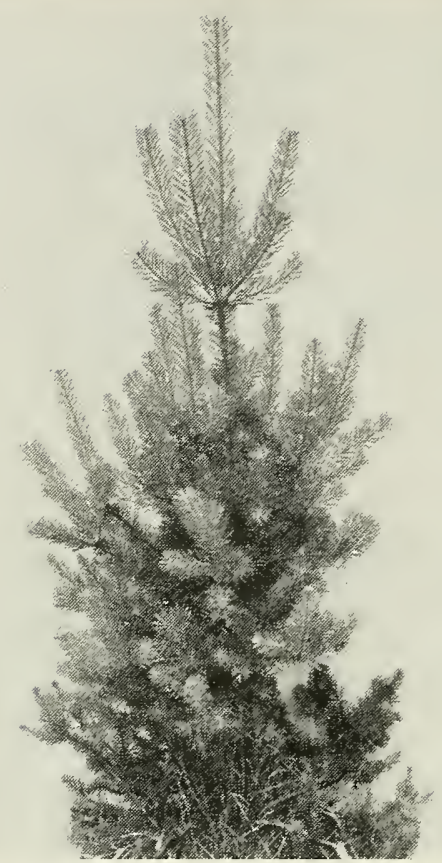

FIGURE 1. Unpruned Scotch pine. Note the open irregular appearance of the tree caused by variations in den. sity and laterals of irregular length.

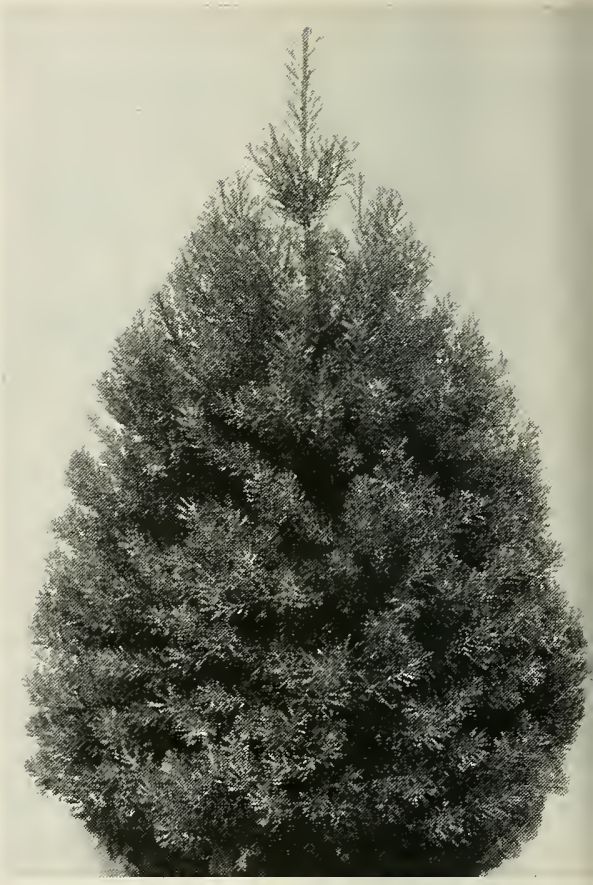

FIGURE 2. Pruned Scotch pine. Note that irregularities in density and outline have been regulated to give an even, conical tree.

for his trees (usually two or three times that of most unsheared trees), but he will also have greater assurance of sales for his product during times of increased competition and oversupply.

A study by Brown (1961) reported the effects of fall and winter pruning on the bud set, bud development, and foliage growth of red, white, and Scotch pine. The purposes of the studies reported here were to test the effects of pruning at various times during the summer on these same characteristics of sheared red, white, and Scotch pines.

\section{Procedure}

Four plantation areas were used in these studies: one was located at an elevation of 1,800 feet, near Bruceton Mills, West Virginia; a second at 2,100 feet, near Reedsville, West Virginia; a third on the West Virginia University Forest east of Morgantown, West Virginia, at an elevation of 2,200 feet; and the fourth near Keysers Ridge, Garrett County, Maryland, at an elevation of 2,450 feet. Thirteen separate groups of trees were used, with trees of each group receiving either 
TABLE 1

Summary of Areas and Species Used in Pruning Studies

\begin{tabular}{|c|c|c|c|c|c|c|}
\hline & $\begin{array}{l}\text { Group } \\
\text { NuMBER }\end{array}$ & SPECIES & $\begin{array}{l}\text { Location of } \\
\text { Plantation }\end{array}$ & $\begin{array}{c}\text { Year First } \\
\text { Pruned }\end{array}$ & $\begin{array}{l}\text { Year Last } \\
\text { Pruned }\end{array}$ & $\begin{array}{l}\text { No. Annual } \\
\text { Prunings }\end{array}$ \\
\hline 1 & $\ldots$ & Scotch pine & Bruceton Mills & 1957 & 1958 & 2 \\
\hline 2 & $\ldots \ldots$ & Red pine & Bruceton Mills & 1957 & 1958 & 2 \\
\hline 3 & $\ldots \ldots \ldots$ & Scotch pine & Reedsville & 1957 & 1960 & 4 \\
\hline 4 & $\ldots \ldots \ldots$ & Red pine & Reedsville & 1957 & 1960 & 4 \\
\hline 5 & & Scotch pine & Reedsville & 1958 & 1960 & 3 \\
\hline 6 & $\cdots$ & Red pine & Reedsville & 1958 & 1960 & 3 \\
\hline 7 & . & White pine & Reedsville & 1958 & 1960 & 3 \\
\hline 8 & & Scotch pine & Reedsville & 1959 & 1960 & 2 \\
\hline 9 & . & White pine & Reedsville & 1959 & 1960 & 2 \\
\hline 10 & & White pine & Reedsville & 1960 & 1960 & 1 \\
\hline 11 & & Red pine & W.V.U. Forest & 1961 & 1962 & 2 \\
\hline 12 & & Scotch pine & W.V.U. Forest & 1961 & 1962 & 2 \\
\hline 13 & & Scotch pine & Maryland & 1961 & 1962 & 2 \\
\hline
\end{tabular}

one, two, three, or four prunings during the summers of 1957 to 1962 (Table 1). Each group consisted of 70 trees, with 10 of these being pruned at each of 6 separate times, early-June, mid-June, early-July, mid-July, early-August, and mid-August. Ten trees of each group were left as unpruned controls.

In pruning, the terminals were sheared to lengths of approximately 9 to 12 inches and laterals were cut to varying lengths to produce a symmetrical and nearly cone-shaped tree (Figure 3). Cuts on terminals were made at an angle of approximately 45 to 60 degrees in order to minimize the number of trees which developed multiple terminals following pruning (Brown 1961). After pruning, a large number of adventitious buds normally formed at the bases of needle fascicles, usually near the ends of the cut stems (Figure 4). Following pruning, information was taken on the progress of the development of these adventitious buds and on the subsequent formation and growth of new limbs from these buds.

\section{Results}

In these studies rather definite patterns of bud set, limb development, and shoot growth on pruned trees appeared for each of the three species tested. These trends and their more important variations are discussed in detail in the sections that follow.

\section{Effect of Time of Pruning on Bud Set And Limb Development on Cut Stems}

One of the primary purposes of pruning pines is to increase the number of whorl limbs on the trees, thereby providing more foliage 


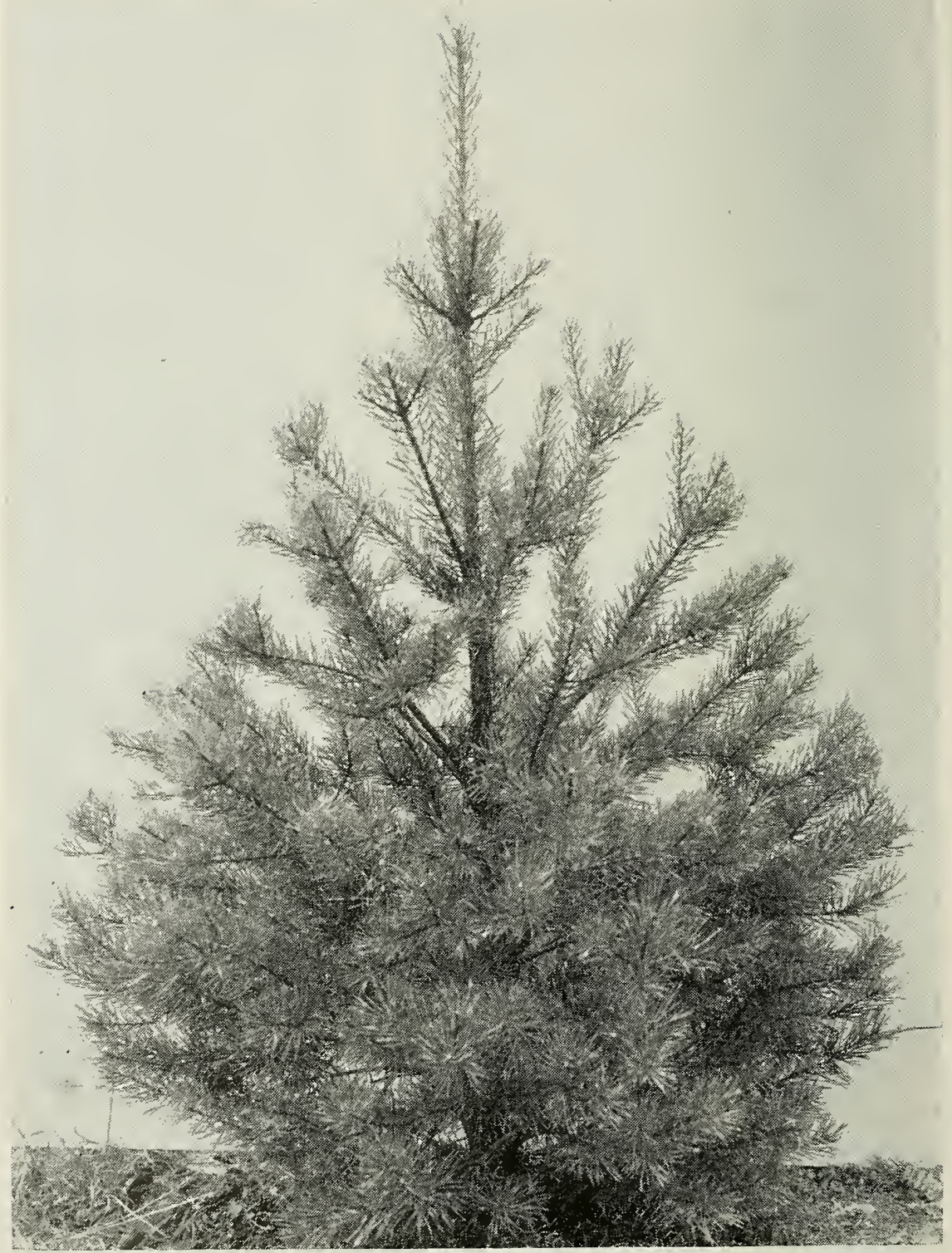

FIGURE 3. Scotch pine immediately after first pruning. Irregularities in outline have been corrected to give an even, conical tree. However, variations in density will not be filled in until additional limbs have formed at the points of pruning. 


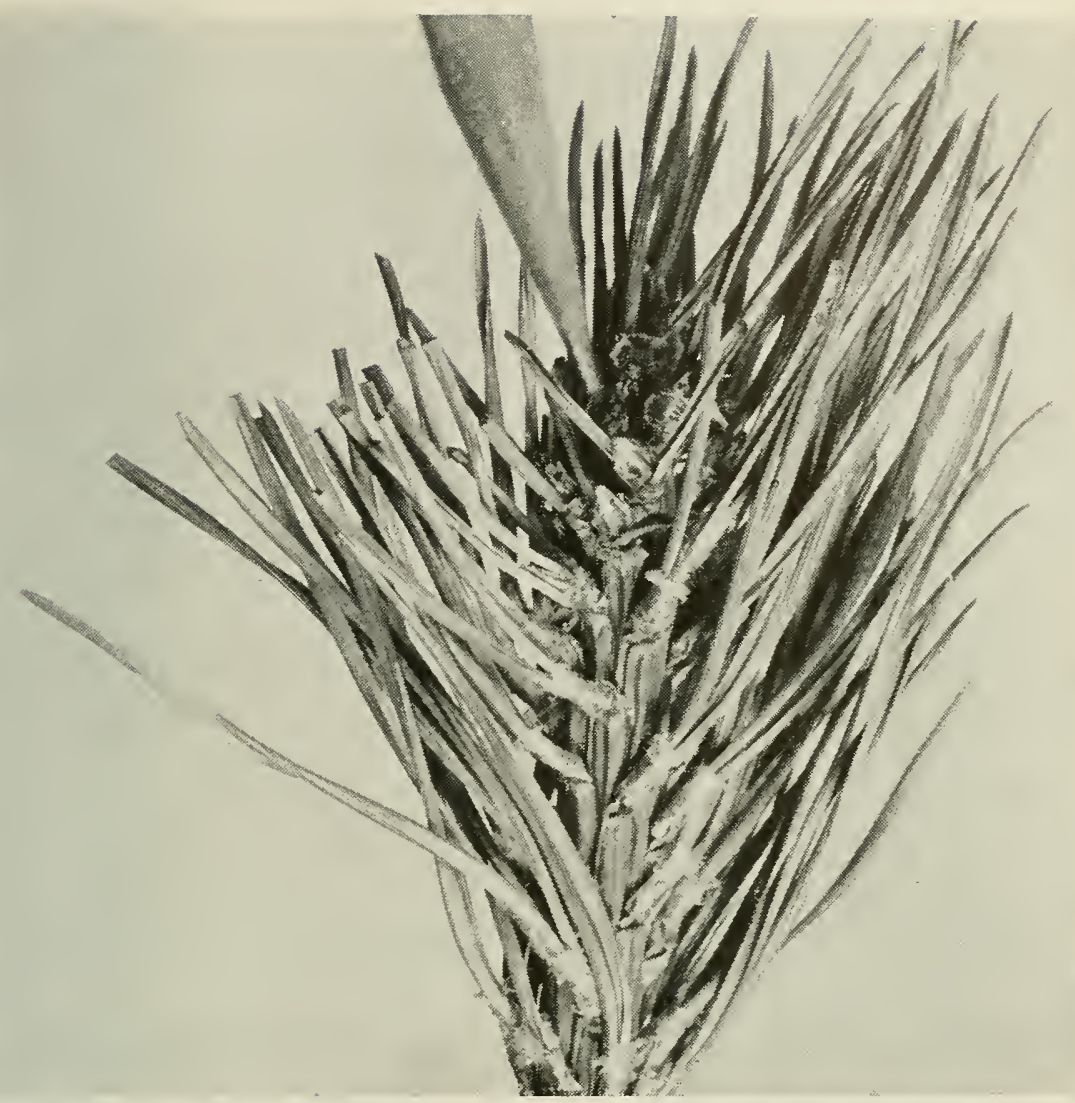

FIGURE 4. New buds forming at the bases of needle fascicles on a pruned Scotch pine terminal.

to give a denser, more even appearing tree. The pattern of bud set and subsequent limb development from buds on trees used in these studies is summarized in Figure 5 and Table 2. Three separate broken line curves are presented for each species (Figure 5). The first of these, number of buds after pruning, summarizes the pattern of formation of new buds on cut terminals. These counts were made in the late fall of the year in which the trees were pruned and, except for variations which will be noted, represent the total number of buds from which the next year's whorl limbs will arise. The second curve, total number of limbs formed on pruned stems, represents the limbs arising from the new buds formed after pruning. These data were taken the summer following shearing. At that time many of the limbs were quite small and weak and it was usually impossible to tell exactly how many and which ones would actually contribute to the foliage 


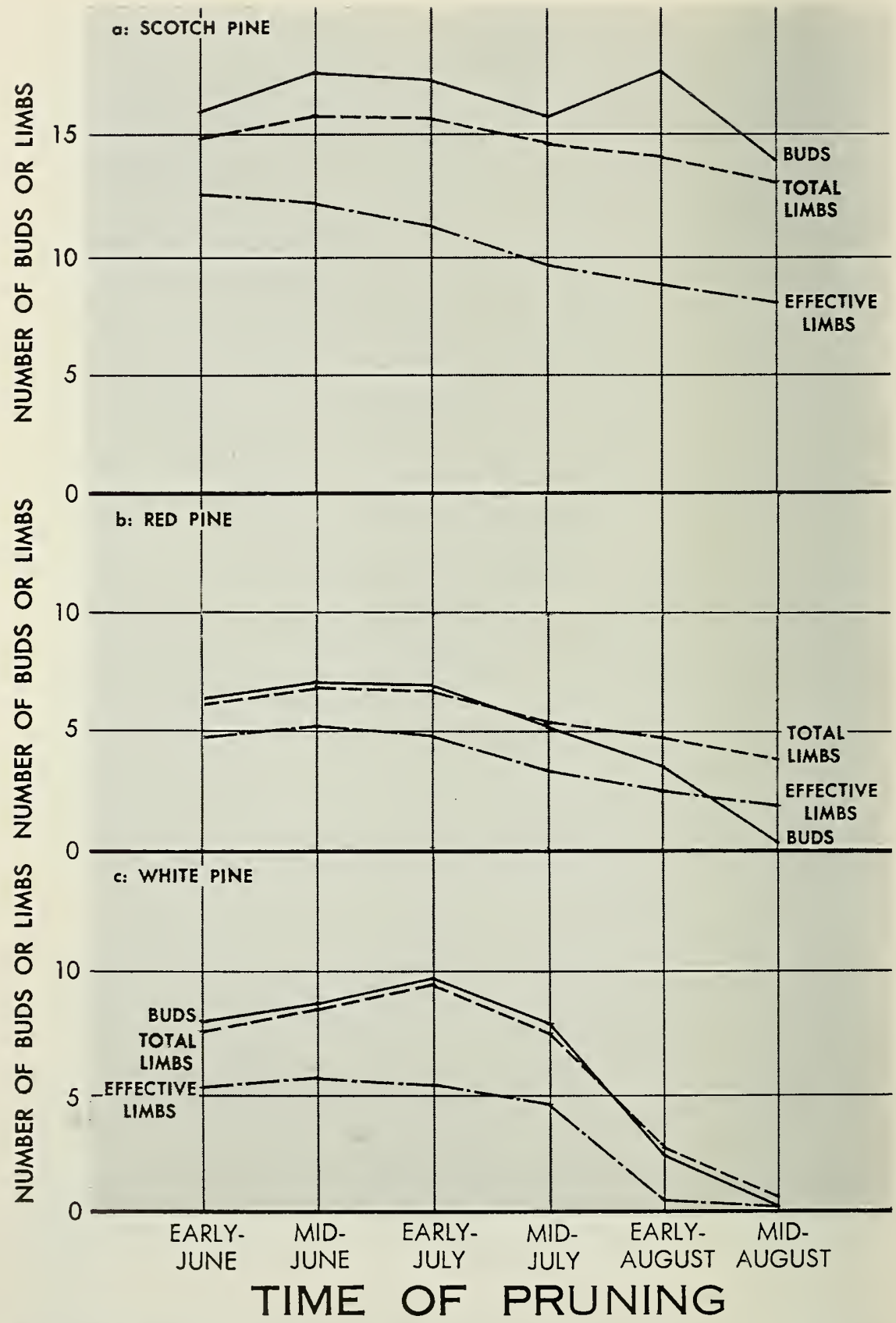

FIGURE 5. Effect of time of pruning on bud and limb development on terminal stems. 
TABLE 2

Comparison of Bud Set, Limb Development, and Terminal Growth on Pruned and Unpruned Trees

\begin{tabular}{|c|c|c|c|c|c|c|c|}
\hline \multirow{2}{*}{ SPECIES AND FACTOR } & \multirow{2}{*}{$\begin{array}{c}\text { LENGTH OF } \\
\text { OR No. ON } \\
\text { CONTROLS }= \\
100 \text { PER CENT }\end{array}$} & \multicolumn{6}{|c|}{$\begin{array}{l}\text { Pruned Trees, by Time of Pruning, } \\
\text { Exphessed as Per Cent of Controls }\end{array}$} \\
\hline & & $\begin{array}{l}\text { Early- } \\
\text { June }\end{array}$ & $\begin{array}{l}\text { Mid- } \\
\text { June }\end{array}$ & $\begin{array}{l}\text { Early- } \\
\text { July }\end{array}$ & $\begin{array}{l}\text { Mid- } \\
\text { July }\end{array}$ & $\begin{array}{l}\text { Early- } \\
\text { August }\end{array}$ & $\begin{array}{l}\text { Mid- } \\
\text { August }\end{array}$ \\
\hline $\begin{array}{l}\text { SCOTCH PINE } \\
\text { Buds After } \\
\text { Pruning }\end{array}$ & 7.2 & 222 & 243 & 238 & 218 & 242 & 196 \\
\hline $\begin{array}{l}\text { Total Limbs, Year } \\
\text { After Pruning } \ldots \\
\text { Effective Limbs, } 2\end{array}$ & 6.9 & 214 & 232 & 227 & 212 & 203 & 191 \\
\hline $\begin{array}{c}\text { to } 4 \text { Years After } \\
\text { Pruning } \ldots . . . . \\
\text { Terminal Growth, Year }\end{array}$ & 6.2 & 200 & 198 & 179 & 156 & 142 & 127 \\
\hline After Pruning & 1.31 (ft.) & 90 & 86 & 73 & 63 & 50 & 36 \\
\hline $\begin{array}{l}\text { RED PINE } \\
\text { Buds After Pruning } \\
\text { Total Limbs, Year }\end{array}$ & 4.1 & 156 & 168 & 158 & 124 & 85 & 10 \\
\hline $\begin{array}{r}\text { After Pruning } \\
\text { Effective Limbs, } 2\end{array}$ & 4.1 & 151 & 163 & 161 & 132 & 117 & 95 \\
\hline $\begin{array}{c}\text { to } 4 \text { Years After } \\
\text { Pruning } \ldots \\
\text { Terminal Growth, Year }\end{array}$ & 3.9 & 117 & 133 & 123 & 82 & 64 & 46 \\
\hline After Pruning & $1.05(\mathrm{ft})$. & 85 & 80 & 61 & 41 & 30 & 17 \\
\hline $\begin{array}{l}\text { WHITE PINE } \\
\text { Buds After Pruning } \\
\text { Total Limbs, Year }\end{array}$ & 7.0 & 113 & 122 & 138 & 113 & 33 & 3 \\
\hline $\begin{array}{c}\text { After Pruning } \\
\text { Effective Limbs, } 2 \\
\text { to } 4 \text { Years After }\end{array}$ & 6.4 & 117 & 134 & 147 & 119 & 42 & 9 \\
\hline $\begin{array}{l}\text { Pruning } \ldots . . . . . \\
\text { Terminal Growth, Year }\end{array}$ & 6.1 & 89 & 100 & 93 & 74 & 10 & 3 \\
\hline After Pruning ... & $1.30(\mathrm{ft})$. & 64 & 58 & 48 & 35 & 8 & 2 \\
\hline
\end{tabular}

density of the tree. The third curve, labeled effective limbs, shows the number which actually contributed to foliage density, and counts for this curve were taken two to four years after the original pruning.

Each individual broken line curve in Figure 5 represents a summary of data for all of the groups of a particular species, as listed in Table 1. For example, the curves for Scotch pine represent six separate groups of trees (Numbers $1,3,5,8,12$, and 13) and fifteen separate prunings ( 2 for group 1,4 for group 2, etc.). Each individual point plotted on the Scotch pine curves thus represents 150 individual prunings of trees, since each group contained ten trees and there were 15 prunings. Even the points on the curves for white pine, for which there were only three groups of trees and six separate prunings, are represented by results for 60 individual prunings. Variations from the overall trends shown in Figure 5 did appear, and some of the more important ones will be discussed later. 
The pattern of bud set and limb development on cut terminals of Scotch pine is summarized in Figure $5 \mathrm{a}$, and it may be seen that the number of buds formed following pruning of this species was quite high after shearing at all six times during the summer. The numbers showed a slight downward trend when prunings were made after mid-June, except for a decided increase in the number formed after prunings made in early-August. The reason for this early-August increase will be discussed later. As shown in Table 2, these values for Scotch pine are from approximately 200 to 250 per cent as great as the number of buds on unpruned trees. These increases on pruned trees were found to be statistically significant, as shown in Appendix Table 1. The total number of limbs formed on Scotch pine showed a pattern similar to that of the number of buds formed (with the exception of the early-August prunings), with actual numbers usually being one or two below the number of buds. The total number of limbs formed after prunings represented values of about 190 to 230 per cent of that found on unpruned controls, with differences being statistically greater for all periods.

Effective limbs actually contributing to the foliage density of the tree showed a somewhat different pattern, with the number being greatest after early-June prunings and declining steadily until the last prunings in mid-August. The divergence between effective limbs and number of buds (unlike that between total limbs and total buds) increased steadily the later the date of prunings. This indicates that although the number of buds formed on terminals of Scotch pine pruned late in the summer is nearly as great as the number formed after earlier prunings, many are weak and small. Although most of these buds develop into limbs, as indicated by the similarity in the two curves for total buds and total limbs, many never grow large enough to contribute to the foliage density of the tree. These small limbs may persist on the inner portions of the whorl, or in some cases they may die after one of two growing seasons (Figure 6). As shown in Table 2, the numbers of effective limbs were 200 per cent as great as those on unpruned controls after early-June prunings and only about 130 per cent as great after mid-August shearings. Statistical tests (Appendix Table 1) showed that these increases were signifcant for all times of prunings. These tests further indicated that the downward trend in number of effective limbs formed after pruning was statistically significant. Limbs formed on trees pruned in early-June were significantly greater in number than those formed on trees pruned in July or August, whereas number of limbs on trees pruned in midJune proved to be significantly greater than those on trees pruned in mid-July or later. When comparing values for mid-June and early- 


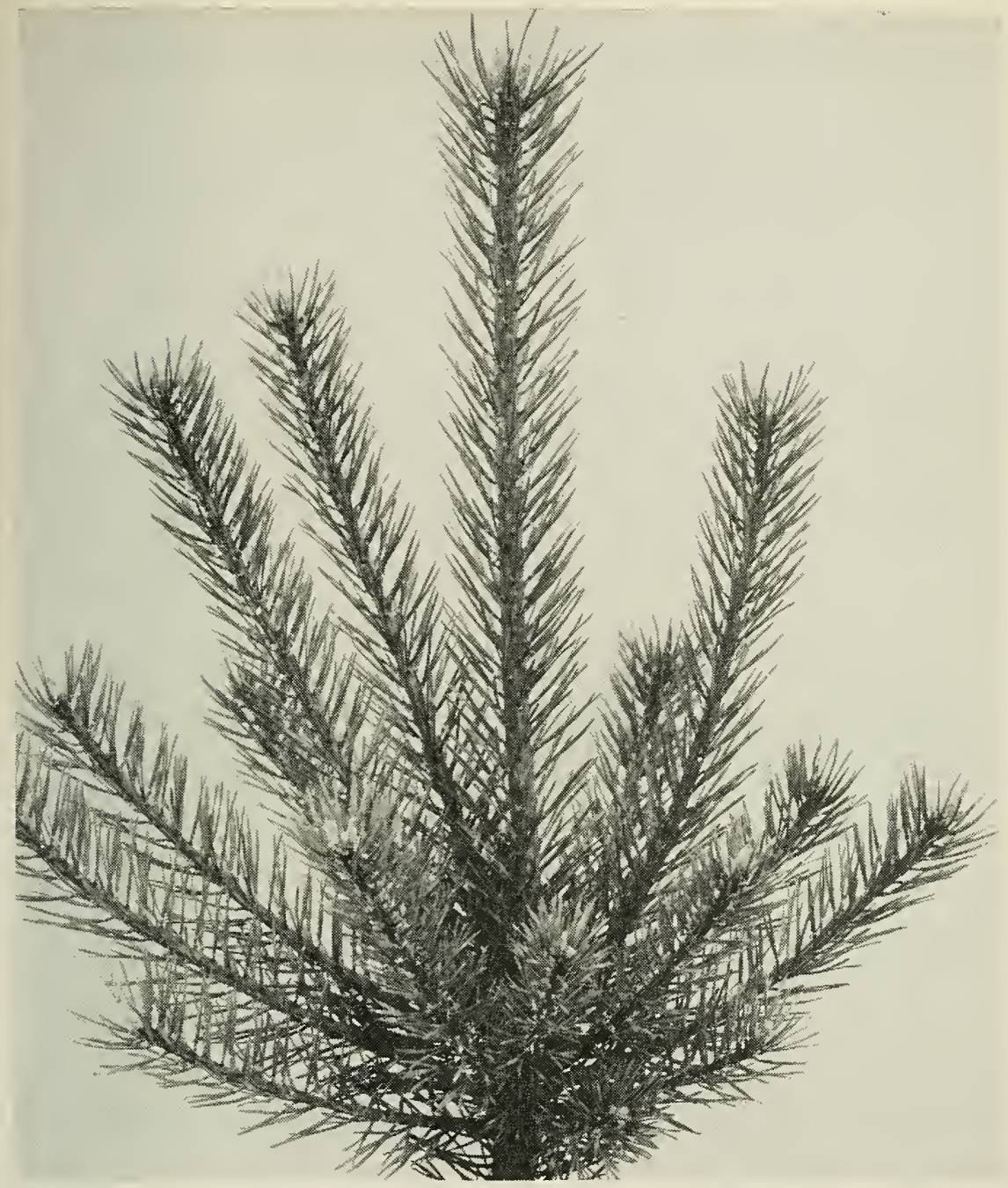

FIGURE 6. Limb development following pruning on Scotch pines. Note the presence of several small limbs, particularly near the bottom of the whorl. Many of these limbs will never develop sufficiently to contribute to the foliage density of the tree.

July, differences approached statistical significance (mean difference of 0.18 for the two periods compared with a " $D$ " value of 0.20 ). This same pattern persisted for all other comparisons between numbers formed after prunings in successive periods (early-July vs. mid-July, mid-July vs. early-August, and early-August vs. mid-August).

The patterns for red pine (Figure $5 \mathrm{~b}$ ) varied somewhat from those of Scotch pine. The number of buds formed the first summer 
after prunings on terminals of red pine was greatest in mid-June and declined steadily until mid-August. In most instances, stems cut in mid-August failed to set buds during the remainder of that first summer and fall after pruning. The number of buds on pruned trees was about 170 per cent of that on unpruned trees after mid-June prunings, and this value decreased to 0 to 10 per cent in mid-August. Numbers of buds were statistically greater (or nearly so) on trees pruned from early-June to mid-July than on unpruned trees, whereas those trees pruned in mid-August had fewer buds than did unpruned trees (Appendix Table 1).

Limb formation showed another quite different pattern, particularly in comparing late-season prunings. The total number of limbs formed was greatest after mid-June prunings and declined slightly but steadily until mid-August. In comparing the late-season values (those after early-July) for buds and total limbs, it will be noted that there were actually more limbs formed than there were buds formed the previous year. This discrepancy can be explained by the fact that on terminals of red pine pruned after early-July, some buds developed during that summer and additional ones were formed the following spring. Only those trees pruned in mid-July or earlier had statistically greater numbers of total limbs than did unpruned trees. The number of effective limbs on red pine was maximum after midJune prunings, with numbers declining steadily to mid-August. In comparing the effective limbs on red pine with unpruned trees, however, only those pruned from early-June to early-July showed increases in numbers (approximately 115 to 135 per cent), while the trees pruned later actually had fewer limbs than did unpruned trees. Of these values, only mid-June prunings produced statistically greater numbers of effective limbs than did unpruned trees, while those pruned in August had statistically fewer limbs.

In some respects the results obtained with white pine were similar to those for red pine. The number of buds formed on pruned terminals of white pine increased slightly from early-June to earlyJuly and then fell off rapidly (Figure 5c). Almost no buds were formed on stems of white pine cut in mid-August, and in many cases stems cut in early-August also failed to set buds. Comparison of pruned and unpruned trees showed that trees sheared in mid-July or earlier had a greater number of buds than unpruned trees, and trees pruned after midJuly showed a decrease in numbers. These differences were statistically significant (Appendix Table 1). Unlike red pine, no appreciable number of new buds formed the following spring on terminals of white pine pruned in late summer. Therefore, the patterns of limb development on white pine followed closely that shown by bud formation, 
with total limbs formed being approximately identical to numbers of buds. Effective limbs showed nearly the same pattern, except that the number declined steadily after mid-June instead of early-July. In comparison with unpruned trees the total number of limbs formed on pruned trees was greater on those sheared in mid-July or earlier and less on those pruned in August. With effective limbs only those trees sheared in June or early-July had nearly as many limbs as did unpruned trees, whereas all trees pruned later showed statistically fewer numbers of limbs than did unsheared trees. For those trees pruned in early-August or mid-August on which buds failed to form, the cut terminals died back and an uncut whorl limb usually turned up and became the new terminal of the tree (Figure 7).

In relation to bud formation after pruning, one factor was quite constant for all three species studied. This was the fact that the later the time of pruning during the summer, the smaller the buds that were formed during that same summer on the cut stems. Those buds formed after early-June shearings were nearly as large as those on unpruned trees, with size generally becoming smaller as later shearings were used. This was culminated in red pine and white pine on which no buds formed after most mid-August prunings. Stems of trees pruned at three separate times during the summer are shown in Figure 8.

Studies by Larsson (1961) indicate that prunings prior to earlyJune are generally not advisable. In these studies he found that immature shoots pruned in May failed to form as many buds or limbs as did those pruned in early-June. Growth on stems pruned in May varied little from stems sheared in June.

\section{Effect of Time of Pruning on Terminal Growth the Following Year}

In the pruning operation, all of the original buds at the tip of the stem which would normally develop into the following year's new whorl of limbs and terminal are removed. Therefore, one or more of the new buds which form on the cut stem must develop into a new terminal or terminals. If shearing has been done properly, as described earlier, one of the buds on the cut stem will occupy a position somewhat above the others. This bud will usually develop into the new terminal of the tree (Brown 1961).

Figure 9 summarizes for all groups of individual species the effects of different times of pruning on subsequent growth of the new terminal which develops on cut stems of Scotch, red, and white pines. The patterns shown by the three separate species in this figure are 


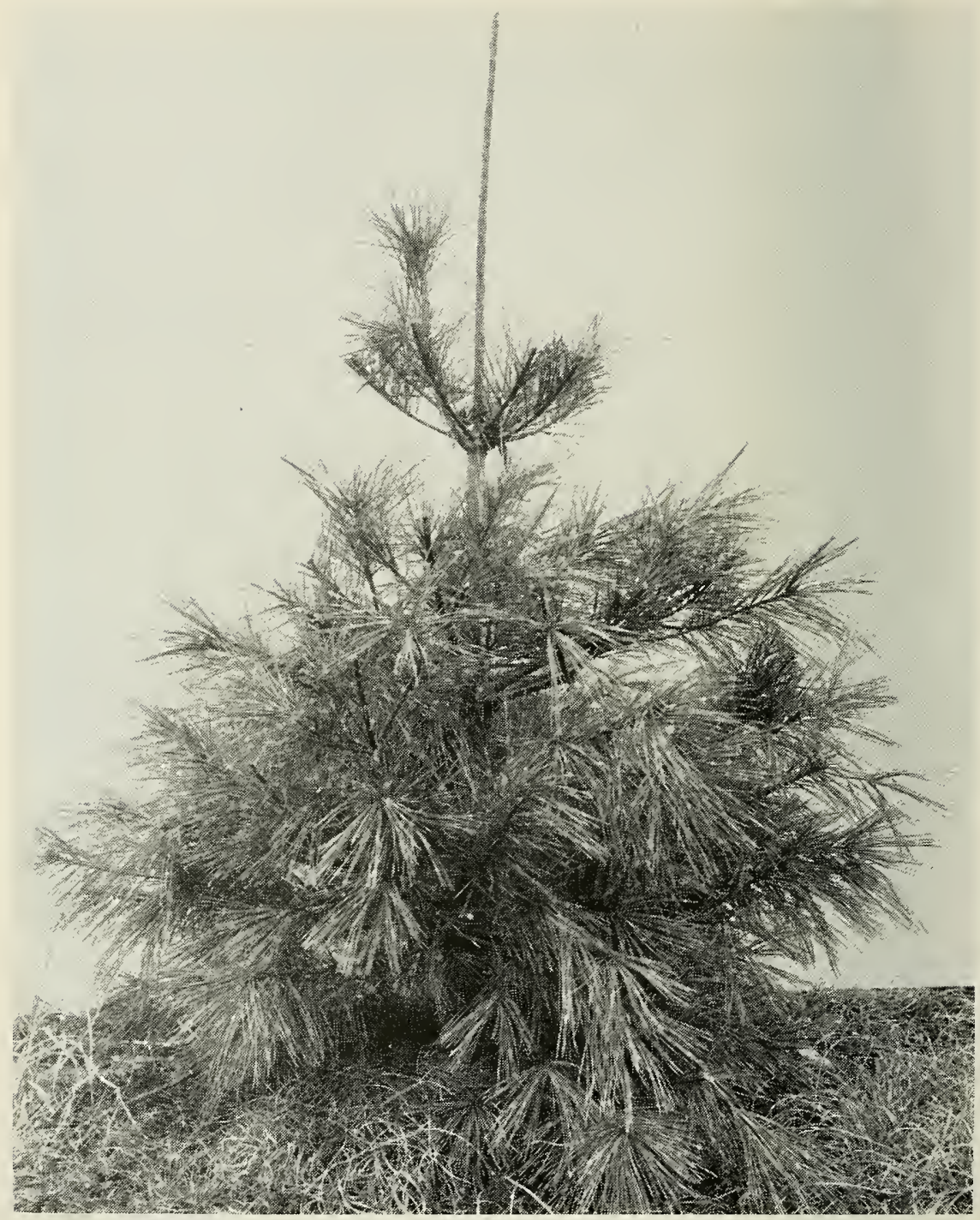

FIGURE 7. White pine one year after pruning made in late-August. The pruned terminal has died and an unpruned lateral is beginning to turn upward.

somewhat similar, with maximum growth occurring on stems pruned in June and growth falling off rapidly as later dates of shearing are used. In the curves for Scotch pine and red pine these relationships are nearly linear, whereas with white pine it is nearly linear for the four earliest pruning dates and then falls off sharply for the August prunings. This sharp break is a reflection of the fact that, as mentioned earlier, few buds formed on stems of white pine sheared in 


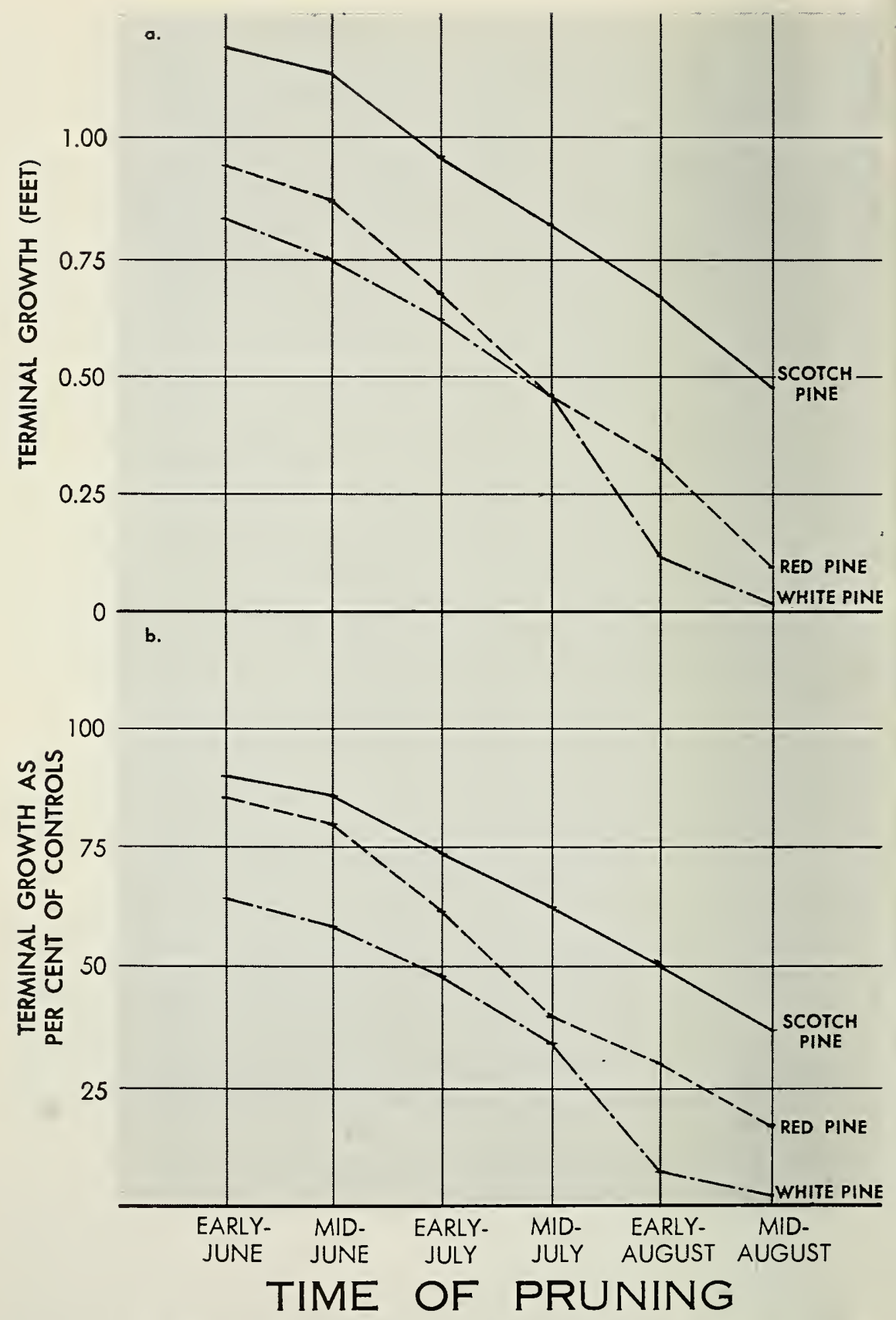

FIGURE 9. Relationship between time of pruning and terminal growth the following year. 

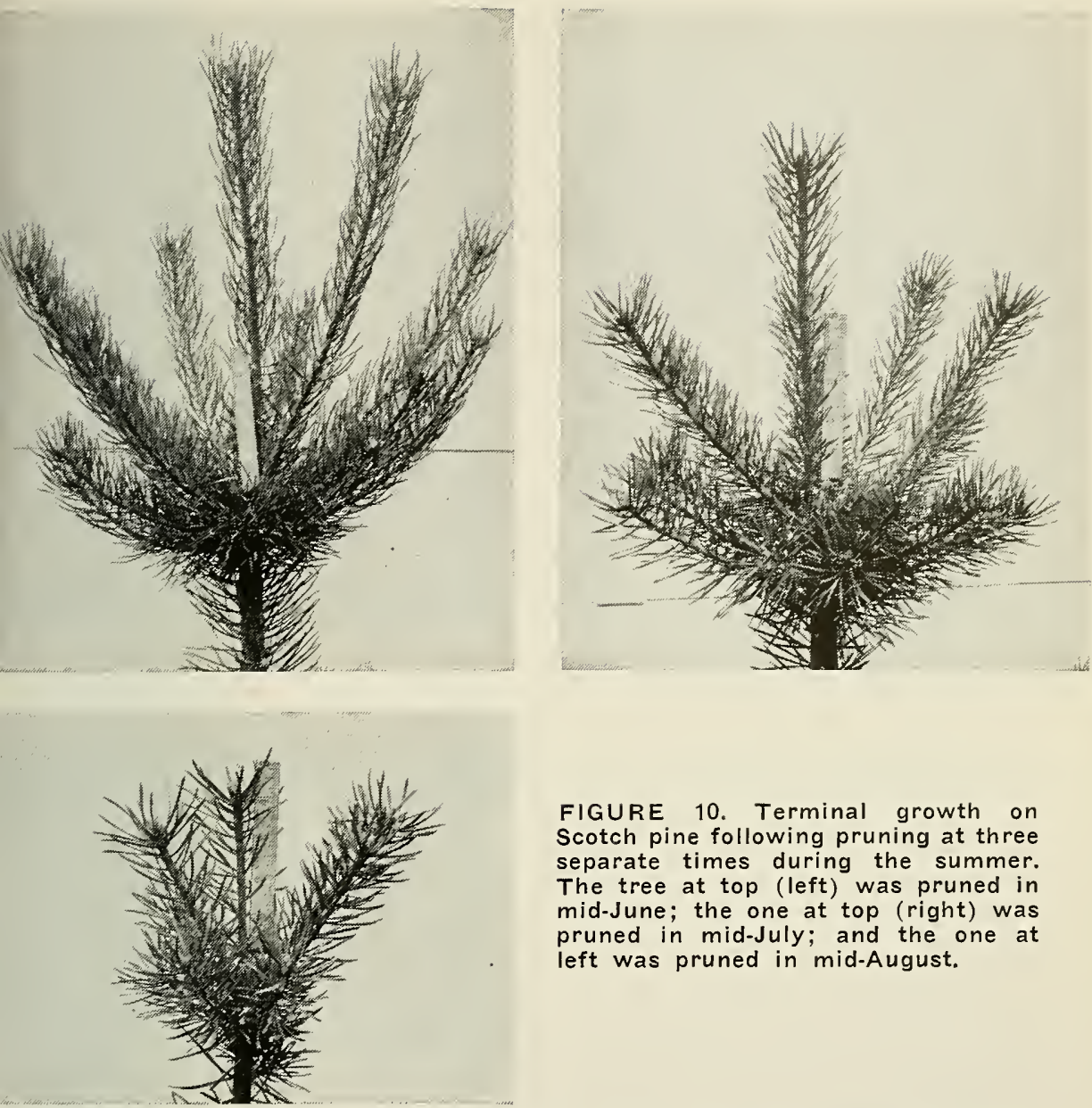

FIGURE 10. Terminal growth on Scotch pine following pruning at three separate times during the summer. The tree at top (left) was pruned in mid-June; the one at top (right) was pruned in mid-July; and the one at left was pruned in mid-August.

early- and mid-August. Usually these buds were so small that they failed to grow at all or grew very little and never developed into normal limbs. Figure 10 shows growth on Scotch pine following pruning at three separate times.

The reason for this decline in growth is related to size of buds formed after the trees were pruned the previous year. It may be recalled that buds become progressively smaller the later the date of pruning. The following spring, when growth usually begins, shoot growth from these smaller buds does not start immediately, but rather buds enlarge for a period of time and then shoot growth begins. The smaller the buds, the longer it takes for this enlargement phase, and, consequently, less time remains for shoot growth. 
Since the normal objective in shearing is to regulate the length of the terminal to approximately 9 to 12 inches, anything that drastically reduces the length of the terminal that forms can be of considerable importance. For example, if growth on the new terminal is only 4 to 6 inches on pruned trees, several additional years may be required to grow the tree to marketable size, all other factors being equal. For this reason the reduction in growth caused by late pruning could be very important. Figure $9 \mathrm{~b}$ shows that even trees sheared in early-June do not show as much growth as do unpruned trees. If the trees to be sheared have considerable growth, the reduction caused by pruning may not be so serious. For example, if a plantation of Scotch pine is to be pruned and terminals on unsheared trees are approximately 20 inches in length, trees pruned in early-July might be expected to show approximately 75 per cent as much growth the following year, or about 15 inches. This would still be sufficient to allow normal pruning. However, if trees to be sheared show only about 10 inches growth, about 7 to 8 inches growth would be expected if they were pruned in mid-July.

\section{Variations in Bud Set and Shoot Development Caused By Differences in Growing Season and Altitude}

The trends in bud set and shoot development discussed earlier were based on averages of all data collected for a particular species. For Scotch pine and red pine this included prunings in six separate years, with four separate locations for Scotch pine and three locations for red pine. For white pine, prunings in three separate years at the same location were included. As might be expected, variations from these averages did occur. These could usually be explained by differences in the growing seasons during which the studies were carried out. Of particular importance was the "lateness" or "earliness" of the growing season, the time at which growth commenced in the spring, because of the effect on the stage of development of the stems at the time when pruning was done.

Several investigators who have studied growth patterns in forest trees have found that there may be considerable differences in the time at which growth commences in the spring. Baldwin (1931) and Cook (1941) studied growth of several northeastern conifers and found variations in starting dates for growth of white pine of nearly a month and for red pine of over two weeks. Dates of cessation of growth also varied, but not so much as did those for initiation of growth. Usually a late start in growth resulted in a reduction in the total length of the growing season. In these studies, and in those of Kramer (1936), 
beginning of height growth in the spring was found to be closely correlated with warming up of temperatures, and cessation in growth was found to be more closely correlated with photoperiod, the relative length of the day and night periods. In other studies with white pine, Husch (1959) found that photoperiod had an overall controlling influence on cessation of leader elongation, with some variations resulting from yearly changes in available soil moisture. Baldwin (1931) and Kramer (1943) also studied the periodicity of growth at widely separated latitudes and found that the date of initiation of growth was later the more northerly the latitude. In studies by Kramer at Durham, North Carolina, and Keene in New Hampshire, growth of planted white pine started nearly one month later in New Hampshire than in North Carolina, while final cessation of growth occurred at nearly the same time at both locations.

In the studies reported here the most noticeable departures from the average trends already discussed were for the years 1959 and 1961. Bud and limb development patterns on Scotch pine for these two years are shown in Figure 11. If this figure is compared with Figure 5a, it may be seen that in 1959 bud set and limb development showed a steady downward trend beginning in early-June, instead of declining after mid-June or early-July. This indicates that growth had progressed further when the first prunings were made in early-June. The situation in 1961 was just the reverse, with development showing a definite lag behind the averages. In both years these differences were most noticeable in the data for early- and mid-June. By the middle of July no significant differences from the average trends could be determined. Deviations similar to those shown by Scotch pine were also shown by red pine and white pine in 1959 and 1961 .

Examination of weather records for the years covered by these studies revealed that temperatures in April and May were probably most important in affecting the growth patterns of the species tested. Temperatures for these months for the years 1957 to 1962 are summarized in Table 3. The table shows that temperatures in 1959 and 1961 (the two years in which bud and limb development varied the greatest from averages) deviated from normal temperatures throughout most of April and May. The April, 1959, temperatures were well above average, except for a short period during the last week of the month. This was followed by temperatures in May that averaged over three and one-half degrees above normal. The April, 1961, temperatures were consistently very low, followed by a cool May in which temperatures averaged over five degrees below normal. As may be seen in Table 3, temperatures in other years deviated somewhat from the averages, but none so consistently, above or below normal or by so 


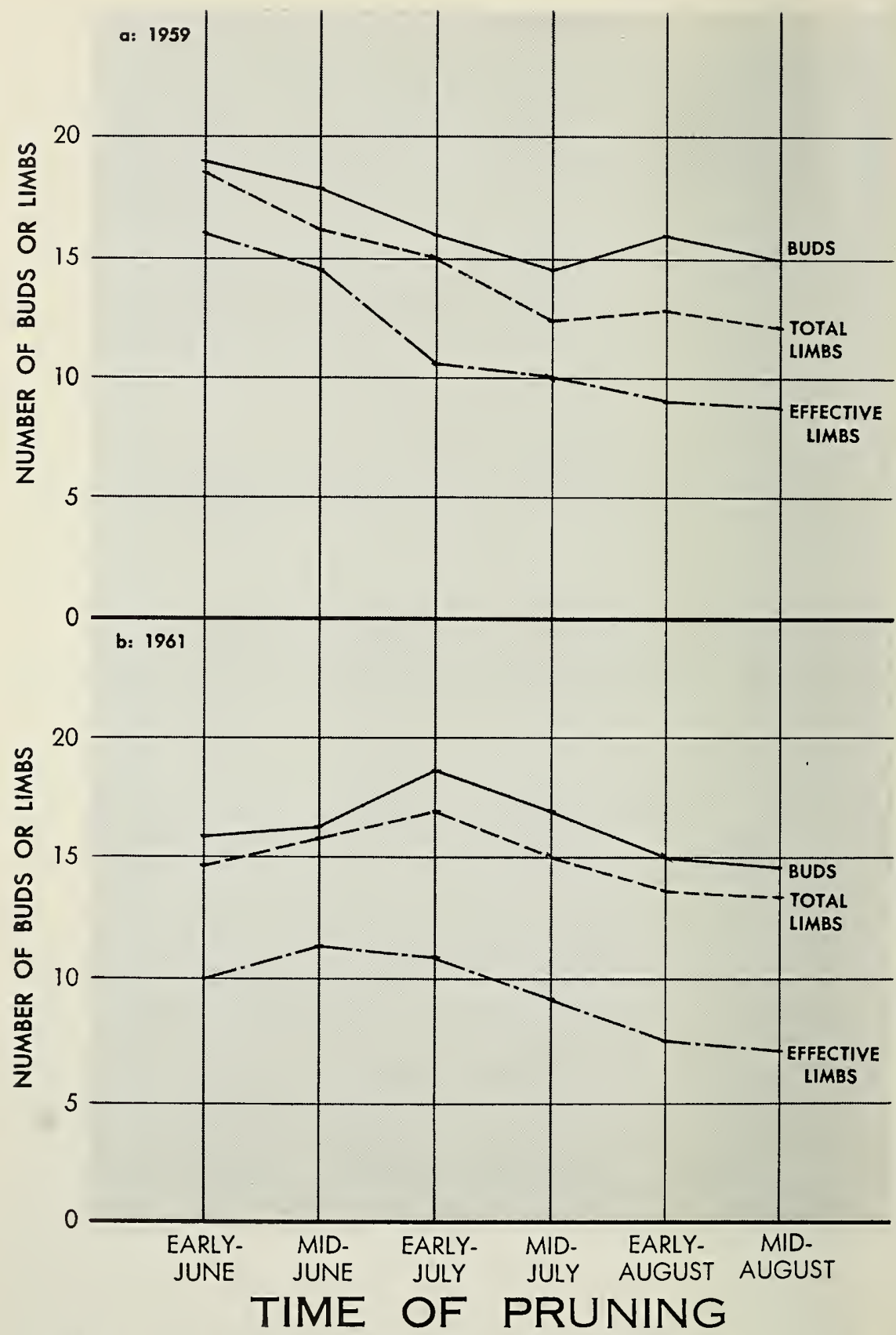

FIGURE 11. Bud set and limb formation on terminal stems of Scotch pine in two years in which temperature patterns deviated the greatest from six-year averages. 


\section{TABLE 3}

Temperature Patterns for the Six-Year Period (1957-1962) During Which Pruning Studies Were Carried Out

\begin{tabular}{|c|c|c|c|c|c|c|}
\hline \multirow{2}{*}{ PERIOD } & \multicolumn{6}{|c|}{ Deviation from Average Temperature for Period and Year } \\
\hline & 1957 & 1958 & 1959 & 1960 & 1961 & 1962 \\
\hline April 1 to April 10 & +1.1 & -1.4 & +10.5 & -0.8 & -7.8 & -1.5 \\
\hline April 1 to April 20 & -0.4 & +1.9 & +6.5 & +2.6 & -6.6 & -4.0 \\
\hline April 1 to April 30 & +2.7 & +0.3 & +2.7 & +3.0 & -6.0 & -2.7 \\
\hline April 1 to May 10 & +1.1 & -0.3 & +3.4 & +1.9 & -4.9 & -0.9 \\
\hline April 1 to May 20 & +1.7 & -0.5 & +2.5 & +0.2 & -4.3 & +0.2 \\
\hline April 1 to May 31 & +1.6 & -1.0 & +3.2 & +0.5 & -5.5 & +1.3 \\
\hline
\end{tabular}

* Temperatures are expressed as deviations, in degrees Fahrenheit, from averages for the periods indicated for the years 1957 to 1962 . Data were from the Brandonville, West Virginia, weather station, which is located within 15 miles of all four areas used in pruning studies.

great amounts as those for 1959 and 1961. In 1957, 1958, 1960, and 1962, bud and limb development patterns conformed fairly closely to those shown in Figure 5.

Efforts were also made to check effects of differences in altitude on pruning results. During the summer of 1958 prunings were conducted at five locations in West Virginia in addition to those previously discussed (Table 1). These were near New Martinsville ( 800 -foot elevation), Pine Grove (1,200-foot elevation), Buckhannon (1,500-foot elevation), Brandonville (1,850-foot elevation), and Reedsville (2,100foot elevation). The only data taken on these trees were number of buds after pruning (no information was taken after 1958). Results of these prunings were somewhat variable, although comparison of the lowest and highest sites involved (New Martinsville vs. Brandonville or Reedsville) showed definite differences in bud set patterns. For example, the maximum bud set at New Martinsville occurred on red pine which was pruned in early- and mid-June, whereas the maximum on trees pruned at Reedsville occurred after early-July shearings. The same trends were shown by prunings of Scotch pine at New Martinsville when compared with those at Brandonville. For white pine, maximum bud set occurred on trees trimmed in mid-June at New Martinsville and on those pruned in mid-July at Reedsville.

Precipitation also had an effect on pruning results, specifically on the number of buds formed after pruning. This was most noticeable on buds formed after late-season prunings; little or no effect could be ascertained on prunings made in the earlier part of the summer. The reason for this difference could not be determined exactly, although it is probably related to the amount of moisture stored in the soil. During the winter and early spring months moisture is being added to the soil, so that when growth begins in the spring there is usually an abundance of water available for it. As the summer pro- 
gresses, moisture is lost through use by plants and evaporation faster than it can be replenished by precipitation. The amount of precipitation can become increasingly important in regulating growth functions under such circumstances.

The effects of late-season precipitation on bud set shows especially well in the data for Scotch pine. In Figure 5a the pattern for bud set on pruned trees is rather uniform, increasing from early- to mid-June and then decreasing steadily until mid-August, except for a decided increase in early-August. This jump was caused by extremely large numbers of buds (often 40 to 50 on a single stem) being formed after mid-August prunings made at Reedsville in 1957, 1958, and 1960, and at Bruceton Mills in 1958. In these instances there was either abundant late-season rainfall or dry weather prior to pruning, followed by a substantial rain at or near the time of pruning. Results in 1957 especially emphasize this relationship. At Bruceton Mills, the pattern of bud set failed to show a jump after early-August prunings, but those at Reedsville showed a very decided increase. Examination of weather records revealed that precipitation was low in both areas for the months of June and July. August precipitation in the Bruceton Mills area was also very low, but in the Reedsville area one sizeable rain occurred during the first week of the month, just after the early-August pruning.

In following the course of limb formation from these buds, it will be noted from Figure $5 \mathrm{a}$ that neither number of effective nor total limbs formed after pruning showed the increase in early-August that was shown by the number of buds formed. This indicated that many of the additional buds formed after late-season prunings were small and did not develop into limbs. Visual examination of such pruned stems confirmed this, and most of the additional buds were found to have died between the time they were formed in the fall and when new growth started the following spring.

\section{Variations in Bud Set, Limb Formation, and Growth On the Terminal and Different Whorls of Limbs}

In previous sections, the patterns of bud set, limb development, and growth following pruning of the terminal were discussed. Of importance also are the results of prunings on the whorl limbs, which must be trimmed in order to shape the tree into an even, conical outline.

To check these effects, data were taken concerning development of buds and limbs originating from prunings on the terminal and the three topmost whorls of limbs. Three separate groups of Scotch pine, three of red pine, and one group of white pine were used for these comparisons. Results are summarized in Table 4. 


\section{TABLE 4}

\section{Bud and Limb Formation on Pruned Stems of Different WhorLS OF LiMBS}

\begin{tabular}{|c|c|c|c|c|c|c|c|c|}
\hline \multirow{3}{*}{ Tmie of Pruning } & \multirow{2}{*}{\multicolumn{2}{|c|}{ Terminal, }} & \multicolumn{6}{|c|}{ NuMbea of Whorl from Terainal } \\
\hline & & & \multicolumn{2}{|c|}{ Whorl 1} & \multicolumn{2}{|c|}{ WHORL 2} & \multicolumn{2}{|c|}{ Wнонц 3} \\
\hline & $\begin{array}{l}\text { No. } \\
\text { Buds }\end{array}$ & $\begin{array}{c}\text { Total No } \\
\text { Limbs }\end{array}$ & $\begin{array}{l}\text { No. } \\
\text { Buds }\end{array}$ & $\begin{array}{c}\text { Total No. } \\
\text { Limbs }\end{array}$ & $\begin{array}{l}\text { No. } \\
\text { Buds }\end{array}$ & $\begin{array}{c}\text { Total No. } \\
\text { Limbs }\end{array}$ & $\begin{array}{l}\text { No. } \\
\text { Buds }\end{array}$ & $\begin{array}{c}\text { Total No. } \\
\text { Limbs }\end{array}$ \\
\hline SCOTCH PINE & & & & & & & & \\
\hline Early-June $\ldots .$. & 18.6 & 17.5 & 6.2 & 6.1 & 6.6 & 6.7 & 5.0 & 4.8 \\
\hline Mid-June & 19.3 & 18.2 & 6.0 & 6.1 & 6.4 & 5.9 & 5.0 & 5.0 \\
\hline Early-July & 19.3 & 20.6 & 6.9 & 6.1 & 6.7 & 6.0 & 5.1 & 4.6 \\
\hline Mid-July & 17.1 & 15.6 & 6.2 & 6.0 & 5.5 & 5.4 & 4.3 & 4.1 \\
\hline Early-August & 29.2 & 18.3 & 6.7 & 6.1 & 7.3 & 5.4 & 4.9 & 3.5 \\
\hline Mid-August & 19.4 & 16.8 & 4.6 & 5.0 & 4.0 & 4.2 & 3.1 & 3.2 \\
\hline (Average) & $(20.5)$ & $(17.8)$ & (6.1) & $(5.9)$ & (6.1) & $(5.6)$ & $(4.6)$ & $(4.2)$ \\
\hline Controls & 6.7 & 6.0 & 4.0 & 3.3 & 3.6 & 3.3 & 3.0 & 2.4 \\
\hline RED PINE & & & & & & & & \\
\hline Early-June & 7.6 & 7.7 & 3.7 & 3.7 & 3.7 & 3.9 & 2.3 & 2.2 \\
\hline Mid-June & 7.8 & 9.3 & 4.1 & 3.9 & 4. & 4.8 & 2.7 & 3.0 \\
\hline Early-July & 8.0 & 8.8 & 4.4 & 4.3 & 4.6 & 5.2 & 2.4 & 3.8 \\
\hline Mid-July & 6.5 & 8.3 & 3.7 & 3.8 & 3.8 & 4.1 & 2.2 & 3.0 \\
\hline Early-August & 5.1 & 7.1 & 1.9 & 3.2 & 2.6 & 2.8 & 1.8 & 2.0 \\
\hline Mid-August & 0.4 & 7.4 & 0.0 & 1.9 & 0.0 & 2.2 & 0.0 & 1.6 \\
\hline (Average) & $(5.9)$ & (8.1) & $(3.0)$ & (3.5) & (3.2) & $(3.8)$ & (1.91) & $(2.6)$ \\
\hline Controls & 3.8 & 4.0 & 1.7 & 1.6 & 1.8 & 1.8 & 1.7 & 1.4 \\
\hline WHITE P1NE & & & & & & & & \\
\hline Early-June & 13.1 & 10.3 & 5.1 & 4.8 & 4.9 & 4.2 & -- & -- \\
\hline Mid-June & 10.5 & 10.3 & 5.5 & 5.5 & 4.7 & 4.3 & & No \\
\hline Early-July & 12.7 & 10.3 & 5.3 & 5.2 & 4.6 & 4.6 & & ata \\
\hline Mid-July & 14.9 & 12.5 & 2.6 & 2.2 & 2.8 & 2.2 & & ken \\
\hline Early-August & 1.1 & 3.1 & 0.9 & 0.0 & 0.5 & 0.0 & -- & - \\
\hline Mid-August & 0.1 & 2.0 & 0.2 & 0.0 & 0.6 & 0.0 & -- & -- \\
\hline (Average) & $(8.7)$ & $(8.1)$ & (3.4) & (3.0) & $(3.0)$ & (2.6) & -- & -- \\
\hline Controls & 6.2 & 6.2 & 3.1 & 3.0 & 3.2 & 3.0 & -- & -- \\
\hline
\end{tabular}

Patterns of bud set and limb development were quite similar for all three species tested. Statistical tests (summarized in Appendix Table 2 ), comparing differences among all means, indicated that for all three species the numbers of buds and limbs formed after prunings on terminals were significantly greater than the numbers formed after prunings on any of the three whorls of limbs. Actual numbers formed were approximately twice as great on the terminals as on whorl limbs. Comparisons also showed no statistical differences between results of prunings on the two uppermost whorls of limbs, while, with one exception, the numbers of buds or limbs formed after pruning on the top two whorls were statistically greater than on the third or lowest whorl tested. In the one exception, number of buds after pruning on Scotch pine, the difference between the means of whorl 1 versus whorl 3 and whorl 2 versus whorl 3 approached the computed value of "D," which would be significant. Thus the trends shown by all three species 
were the same, with maximum bud set and limb development from prunings on terminals, approximately equal numbers on the first two whorls of limbs, and the least number (of those whorls tested) on the third or lowest whorl.

Analysis of stem growth on the terminal and three whorls of limbs indicated precisely the same pattern as that shown by bud and limb formation. Statistical tests (Appendix Table 2) revealed that maximum growth occurred on terminals, while there were no statistical differences in growth on the two uppermost whorls of limbs. Growth from the third whorl was significantly less than that on the terminal or two whorls above.

\section{Differences in Bud Set and Limb Development After First and Later Prunings}

Table 5 summarizes the results of first and later prunings on the same groups of trees. For the purpose of making comparisons, data for all second, third, and fourth prunings were combined. This was possible because no differences among results of these later prunings could be determined.

Statistical tests, summarized in Appendix Table 3, showed that first prunings produced greater numbers of buds, total limbs, and effective limbs than did later shearings on the same trees. These differences were significant for all three species. Differences were greatest for buds after pruning, with increases in numbers averaging from 30 to 50 per cent. Increases in total number of limbs formed after first prunings ranged from 15 to 25 per cent, and numbers of effective limbs had similar increases. Of the three species, Scotch pine had the greatest increases in bud set and limb formation, followed by red pine and then white pine.

\section{Needle Length as a Guide to Proper Time to Prune}

The ratio of the length of the new needles on the developing stem to the length of the old needles on the previous year's terminal was evaluated, during the course of these studies, as a possible guide or aid in determining the best time to prune. In arriving at this ratio, new needles from the base of the newly developing terminal were measured and this length was compared with the length of needles at the base of the old terminal. A summary of ratios, by year and species, is presented in Table 6. The averages presented for each species in this table are not completely reliable estimates of long-term means since only six years' data for Scotch and red pine and three years' data for white pine are presented. However, they can be used as indicators. 
TABLE 5

Bud Set and Limb Formation After Different Prunings

\begin{tabular}{|c|c|c|c|c|c|c|}
\hline \multirow[t]{2}{*}{ Time of Pruning } & \multicolumn{2}{|c|}{$\begin{array}{c}\text { Buds After } \\
\text { Phuning }\end{array}$} & \multicolumn{2}{|c|}{$\begin{array}{c}\text { TOTAL LIMBS } \\
\text { FOMMED }\end{array}$} & \multicolumn{2}{|c|}{$\begin{array}{c}\text { FFFECTIVE } \\
\text { LiMBS Formed }\end{array}$} \\
\hline & First ${ }^{\circ}$ & Later" & First ${ }^{\circ}$ & Later & First & Later \\
\hline 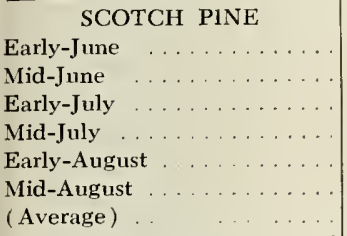 & $\begin{array}{c}18.2 \\
18.4 \\
20.2 \\
19.7 \\
25.7 \\
18.6 \\
(20.3)\end{array}$ & $\begin{array}{c}14.3 \\
16.3 \\
14.0 \\
13.2 \\
12.5 \\
11.0 \\
(13.6)\end{array}$ & $\begin{array}{l}16.3 \\
16.7 \\
18.2 \\
17.5 \\
19.0 \\
18.6 \\
(18.7)\end{array}$ & $\begin{array}{l}13.6 \\
14.9 \\
12.7 \\
11.7 \\
10.6 \\
11.7 \\
(12.5)\end{array}$ & $\begin{array}{c}13.1 \\
12.4 \\
12.1 \\
11.5 \\
10.0 \\
8.6 \\
(11.3)\end{array}$ & $\begin{array}{c}11.8 \\
11.8 \\
10.1 \\
8.9 \\
8.0 \\
8.3 \\
(9.8)\end{array}$ \\
\hline 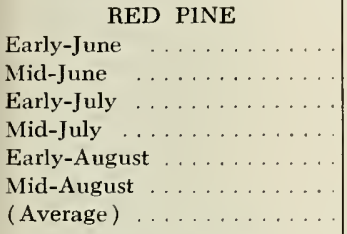 & $\begin{array}{c}7.2 \\
7.8 \\
7.8 \\
7.0 \\
5.6 \\
0.7 \\
(6.0)\end{array}$ & $\begin{array}{c}6.8 \\
6.3 \\
5.8 \\
3.5 \\
3.3 \\
0.1 \\
(4.3)\end{array}$ & $\begin{array}{c}6.8 \\
7.6 \\
7.3 \\
7.4 \\
6.3 \\
6.2 \\
(6.9)\end{array}$ & $\begin{array}{c}6.6 \\
6.1 \\
5.9 \\
4.1 \\
4.7 \\
3.2 \\
(5.1)\end{array}$ & $\begin{array}{c}6.0 \\
5.6 \\
5.2 \\
3.8 \\
3.3 \\
2.4 \\
(4.4)\end{array}$ & $\begin{array}{c}5.1 \\
5.2 \\
4.4 \\
2.4 \\
2.6 \\
1.8 \\
(3.6)\end{array}$ \\
\hline 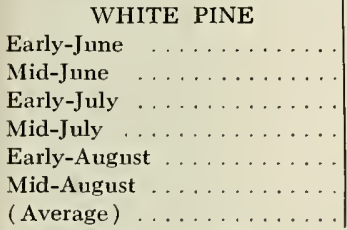 & $\begin{array}{r}8.5 \\
9.8 \\
10.6 \\
10.7 \\
1.7 \\
0.1 \\
(6.9)\end{array}$ & $\begin{array}{c}7.2 \\
7.5 \\
9.0 \\
7.2 \\
1.0 \\
0.0 \\
(5.3)\end{array}$ & $\begin{array}{c}7.9 \\
9.5 \\
9.4 \\
8.8 \\
2.6 \\
1.0 \\
(6.5)\end{array}$ & $\begin{array}{c}7.1 \\
7.5 \\
8.4 \\
7.7 \\
2.0 \\
0.0 \\
(5.5)\end{array}$ & $\begin{array}{c}5.6 \\
6.4 \\
5.8 \\
5.6 \\
1.0 \\
0.5 \\
(4.2)\end{array}$ & $\begin{array}{c}5.4 \\
5.8 \\
5.1 \\
4.5 \\
0.3 \\
0.3 \\
(3.6)\end{array}$ \\
\hline
\end{tabular}

* In data for bud and limb formation, comparison is presented for first prunings as compared to averages for all later prunings (2nd, 3rd, and 4 th). Such grouping was used because no variations could be determined between results of these later prunings.

This ratio of length of new needles to old needles was found to be a rather reliable guide to the stage of stem development, and therefore to pruning results. Examination of Table 6 shows that there was considerable variation in ratios from one year to another, particularly in the early-season values, where differences were found to be closely correlated with variation in temperature patterns during the early portion of the growing season, particularly in April and May. Notable among these differences are the values for 1959 and 1961, which, as previously discussed, were years in which temperatures in April and May varied consistently in one direction from long-time averages. It will be recalled that 1959 had an abnormally early growing season, while 1961 was late. In both of these years, temperature variations were reflected in results obtained from early- and mid-June prunings. Table 6 shows that when prunings were begun in earlyJune of 1959 new needles were considerably longer than usual. For Scotch pine the ratio was 0.79 compared with the six-year average of 0.56 , and for red pine the ratio was 0.47 compared with the 
TABLE 6

Summary of Ratios of Lengths of New Needles to Lengths of Old Needles at Various Times of Pruning of Scotch, Red, And White Pines

\begin{tabular}{|c|c|c|c|c|c|c|c|}
\hline \multirow[t]{2}{*}{ Spectes } & \multirow[t]{2}{*}{ YEAR } & \multicolumn{6}{|c|}{ Needle Ratio at Time of Pruning $=\frac{\text { Length of New Needles }}{\text { Length of Old Needles }}$} \\
\hline & & $\begin{array}{l}\text { Early- } \\
\text { June }\end{array}$ & $\begin{array}{l}\text { Mid- } \\
\text { June }\end{array}$ & $\begin{array}{l}\text { Early- } \\
\text { July }\end{array}$ & $\begin{array}{l}\text { Mid- } \\
\text { July }\end{array}$ & $\begin{array}{l}\text { Early- } \\
\text { August }\end{array}$ & $\begin{array}{l}\text { Mid- } \\
\text { August }\end{array}$ \\
\hline \multirow{7}{*}{ Scotch pine } & 1957 & 0.64 & 0.87 & 1.02 & 1.12 & 1.14 & 1.10 \\
\hline & 1958 & 0.50 & 0.76 & 0.92 & 1.03 & 1.11 & 1.15 \\
\hline & 1959 & 0.79 & 0.93 & 1.03 & 1.07 & 1.10 & 1.12 \\
\hline & 1960 & 0.53 & 0.74 & 1.01 & 1.15 & 1.18 & 1.15 \\
\hline & 1961 & 0.38 & 0.52 & 0.75 & 0.92 & 1.03 & 1.02 \\
\hline & 1962 & 0.50 & 0.77 & 0.95 & 1.08 & 1.20 & 1.25 \\
\hline & (Average) & $(0.56)$ & $(0.77)$ & $(0.95)$ & (1.06) & (1.13) & $(1.13)$ \\
\hline \multirow{7}{*}{ Red pine } & 1957 & 0.40 & 0.67 & 0.73 & 1.02 & 1.14 & 1.17 \\
\hline & 1958 & 0.32 & 0.47 & 0.68 & 0.83 & 1.11 & 1.09 \\
\hline & 1959 & 0.47 & 0.72 & 0.93 & 1.13 & 1.15 & 1.14 \\
\hline & 1960 & 0.32 & 0.45 & 0.70 & 0.84 & 0.99 & 1.10 \\
\hline & 1961 & 0.25 & 0.42 & 0.62 & 0.85 & 1.02 & 1.13 \\
\hline & 1962 & 0.34 & 0.56 & 0.98 & 1.20 & 1.25 & 1.22 \\
\hline & (Average) & $(0.35)$ & $(0.56)$ & $(0.77)$ & $(0.98)$ & (1.11) & $(1.14)$ \\
\hline \multirow{4}{*}{ White pine } & 1958 & 0.38 & 0.59 & 0.69 & 0.88 & 0.95 & 1.03 \\
\hline & 1959 & 0.46 & 0.67 & 0.95 & 1.13 & 1.15 & 1.14 \\
\hline & 1960 & 0.39 & 0.53 & 0.75 & 0.94 & 1.05 & 1.13 \\
\hline & (Average) & $(0.41)$ & $(0.60)$ & $(0.80)$ & $(0.98)$ & (1.05) & (1.10) \\
\hline
\end{tabular}

average of 0.35 . In 1961 this pattern was reversed with ratios in early-June running well below the averages.

In other years slight variations from the averages can be noted, and these also can be correlated fairly closely with temperature patterns. In 1957 early-June ratios indicated that needles were slightly longer than average. This was correlated with temperatures which were about average in early-April, high in late-April, and about one degree above normal in May. In 1958 and 1962 temperatures were generally slightly lower than normal and this is reflected in the needle ratios which were also slightly below average. In 1960 temperatures and needle ratios were both about normal.

If the average values in Table 6 are used as a guide, it would appear that in early-June of a year in which temperatures are near average the length of new needles on Scotch pine would be approximately one-half as long as the old needles, and new needles of red pine would be about one-third as long as old ones. For white pine the figure is somewhat less reliable, since only three years' data are represented, but it would appear that values for red and white pines would be fairly comparable. Therefore, these early-June ratio values 
could be used as an indicator of stem development, and thereby as an indirect clue to results of pruning.

For example, if a comparison in early-June of needles on Scotch pine showed that new needles were three-tenths as long as old ones, an unusually late growing season would be indicated. In such a year results of prunings in late-June or early-July would approximate those of early- or mid-June in a normal year. In such a year small trees could be pruned later than usual with acceptable results. On the other hand, if needle ratios indicated a particularly early growing season it would be well to prune small trees as early as possible in the summer so that growth the following year would be sufficient to allow for normal pruning.

An interesting fact that might be noted from Table 6 is that (at least within the range of tree sizes utilized in these studies) length of new needles on Scotch, red, and white pines increased slightly each year over the length of needles formed the previous year. In most years this increase averaged between 10 and 20 per cent, as shown by the values for mid-August. It might also be noted from Table 7 that needle growth commonly continues past mid-July and often into August. This is considerably later than shoot growth which has normally been completed by early- or mid-June.

\section{Summary and Conclusions}

Pruning or shearing of pines is of great importance if high quality Christmas trees are to be produced. In these studies Scotch pine, red pine, and white pine were pruned at six separate intervals during the summer months over a six-year period. Quite different results were obtained from shearings made at different times. Rather distinct patterns of bud set, limb formation, and shoot growth were determined for each of the species tested, and each of these trends can have an important bearing on tree development.

Formation of buds on pruned stems varied somewhat among the three species. For Scotch pine and red pine the maximum numbers of buds were formed after mid-June shearings, with the number declining as later trimmings were used. For white pine, maximum numbers of buds were formed after shearings made in early-July, with the number declining rapidly as mid-July or August prunings were used. For Scotch pine, numbers formed on trimmed stems were greater at all times than the numbers on unpruned controls. For red and white pines, only those trees pruned in June or July formed greater numbers of buds than were formed on unsheared trees. 
The total number of limbs formed usually followed patterns very similar to those shown by bud formation. One notable exception was limb formation after late-season prunings of red pine, where greater numbers of limbs were formed than there were buds formed during the previous growing season. These additional limbs originated from buds which were formed the spring after prunings. With the addition of these extra buds and limbs, all pruned stems of red pine, except those pruned in mid-August, had greater numbers of total limbs than did unpruned trees, while white pine, pruned in August, had fewer limbs than did unpruned trees.

Trends in the two factors which are probably of greatest importance to proper development of a well-sheared Christmas tree were fairly constant. These factors are shoot growth after pruning and the number of effective limbs formed-the limbs which actually contribute to making the tree more dense. Trends in both of these indicated the importance of early-summer pruning.

The number of effective limbs formed varied only slightly. For Scotch pine, maximum numbers occurred after early-June prunings with the number decreasing steadily as later shearings were used. With red and white pines, this trend was modified slightly, with even numbers or a slight build up in June, followed by a steady decline in July and August. In the case of white pine, usually no limbs formed after mid-August prunings. For Scotch pine, numbers of effective limbs were greater than the numbers of effective limbs on unpruned trees, regardless of time of shearing. For red pine, only those trees pruned in June or early-July showed increases, and for white pine the number of effective limbs on pruned trees never exceeded those on unpruned trees. Only those white pines pruned in June or early-July had nearly the same number of effective limbs as did unpruned trees, while those pruned in mid-July showed slight decreases in the number of limbs, and those pruned in August showed decided decreases or no limb formation.

Shoot growth followed a pattern quite similar to that for effective limb formation, except that for all three species maximum growth occurred on early-June pruned stems, and growth declined steadily on those sheared later in the summer. For white pine, trees trimmed in mid-August usually failed to produce any new growth, and pruned stems normally died back to an unpruned whorl.

An important consideration related to shoot growth was the fact that even with early-June prunings the growth on trimmed trees was not so great as that on unpruned trees. Early-June sheared Scotch and red pines had approximately 85 to 90 per cent as much growth as unpruned trees, whereas white pine trimmed at the same time had 
only about 65 per cent as much growth as did unpruned trees. In mid-July these values were about 65 per cent for Scotch pine and less than 50 per cent for red and white pine. Mid-August values were 36 per cent for Scotch pine, 17 per cent for red pine, and only 0 to 5 per cent for white pine.

The implications of this growth pattern could be quite important to the Christmas tree grower. In young plantations, for example those only three to four feet in height, new terminal growth just begins to exceed 12 inches. Therefore it is important to prune these trees in early summer, preferably in early- or mid-June, to insure that growth the following year will be sufficient to allow normal shearing. On the other hand, in pruning older trees where terminal growth is greater, say 20 inches, it would be possible to trim later in the summer and still have sufficient growth the next year to allow normal prunings. Therefore, if a Christmas tree grower has a large number of trees of several size classes, it would be well for him to schedule operations to work over the smaller trees that need pruning first and leave the larger trees until last if operations are to be extended into July or August.

The principal factors which could modify the patterns that have previously been discussed are seasonal differences in growing conditions and significant changes in latitude and/or altitude from those of the areas utilized in these studies. Temperature variations would be most important in their effects on early-summer pruning, for results of these studies indicated that differences caused by "early" or "late" growing seasons were confined largely to early prunings. Little or no effect on shearings made in late July or August could be determined. Variations in rainfall patterns were most effective in causing differences in bud set on stems pruned late in the growing season, and any extra buds formed usually did not develop into effective limbs.

Another factor which could be important in shearing was revealed in these studies. Pruning at different levels on the trees produced differences in results. Maximum bud set, limb development, and shoot growth originated from shearings on the terminal, with equal results from prunings on the two topmost whorls (but fewer numbers or less growth than on the terminal). Fewer buds and less growth occurred after pruning on the third whorl of limbs, the lowest of those tested. In pruning, this pattern can be utilized in developing a properly tapered tree. If a narrow, conical outline is desired, it will be necessary to prune fairly heavily on the upper whorls, with somewhat less shearing on lower whorls. If a broad outline is desired, the amount of trimming needed on upper whorls will be less. 
First prunings on trees were found to produce more buds and limbs than any of the succeeding prunings which might be carried out on the same trees. These differences were greatest for bud formation and somewhat less for total and effective limb formation. Scotch pine showed the greatest increase in numbers after first prunings when compared with later ones, followed by red pine and then white pine.

The ratio of length of new needles on developing shoots to length of old needles on the previous year's terminal was found to be a reliable indicator of early-season growth patterns in the three species tested. Since these growth patterns can effect the results of pruning, needle ratios provide an excellent indirect clue to results which can be expected from shearings. In early-June, average lengths of new needles on Scotch pine were approximately one-half those of old needles. Similar early-June ratios for red and white pines were approximately onethird those of old needles. If needle measurements taken in early-June exceed those ratios, an early growing season is indicated. In such a year it would be well to confine pruning to the earlier part of the summer (June and early-July) if possible. If needle measurements taken in early-June indicate a late season, pruning can probably be extended into late-July with good results.

\section{Literature Cited}

Baldwin, Henry I. 1931. The period of height growth in some northeastern conifers. Ecology 12:665-689.

Brown, James H. 1960. Fall and winter pruning of pines. W. Va. Univ. Agr. Exp. Sta. Current Report 26. 7 pp.

1961. Slope or flat pruning of pines-an important consideration in Christmas tree plantation management. Journal of Forestry 59:213-214.

Cook, David B. 1941. Five seasons' growth of conifers. Ecology 22:285-296.

Husch, B. 1959. Height growth of white pine in relation to selected environmental factors on four sites in southeastern New Hampshire. Univ. of New Hampshire Agr. Exp. Sta. Technical Bull. 100. 42 pp.

Kramer, Paul J. 1936. Effect of variation in length of day on growth and dormancy of trees. Plant Physiology 11:127-137.

1943. Amount and duration of growth of various species of tree seedlings. Plant Physiology 18:239-251.

Larsson, H. C. 1961. The shaping of pine trees by pruning and shearing. American Christmas Tree Growers' Journal, Vol. V, No. 2:10-14, 32-34.

Mitchell, Glen H. and James G. Kendrich. 1960. Production of Christmas trees within selected states in the north central region during the period 19481956. American Christmas Tree Growers' Journal, Vol. IV, No. 4:17-19, 37.

Snedecor, George W. 1956. Statistical methods applied to experiments in agriculture and biology. The Iowa State College Press, Ames, Iowa. xii $+534 \mathrm{pp}$.

Sowder, A. M. 1956. 1955 Christmas tree data. Journal of Forestry 54:843-844. 1961. 1960 Christmas tree data. Journal of Forestry 59:829-830.

United States Weather Bureau, Climatological Data, West Virginia Section. 1957 to 1962 . 


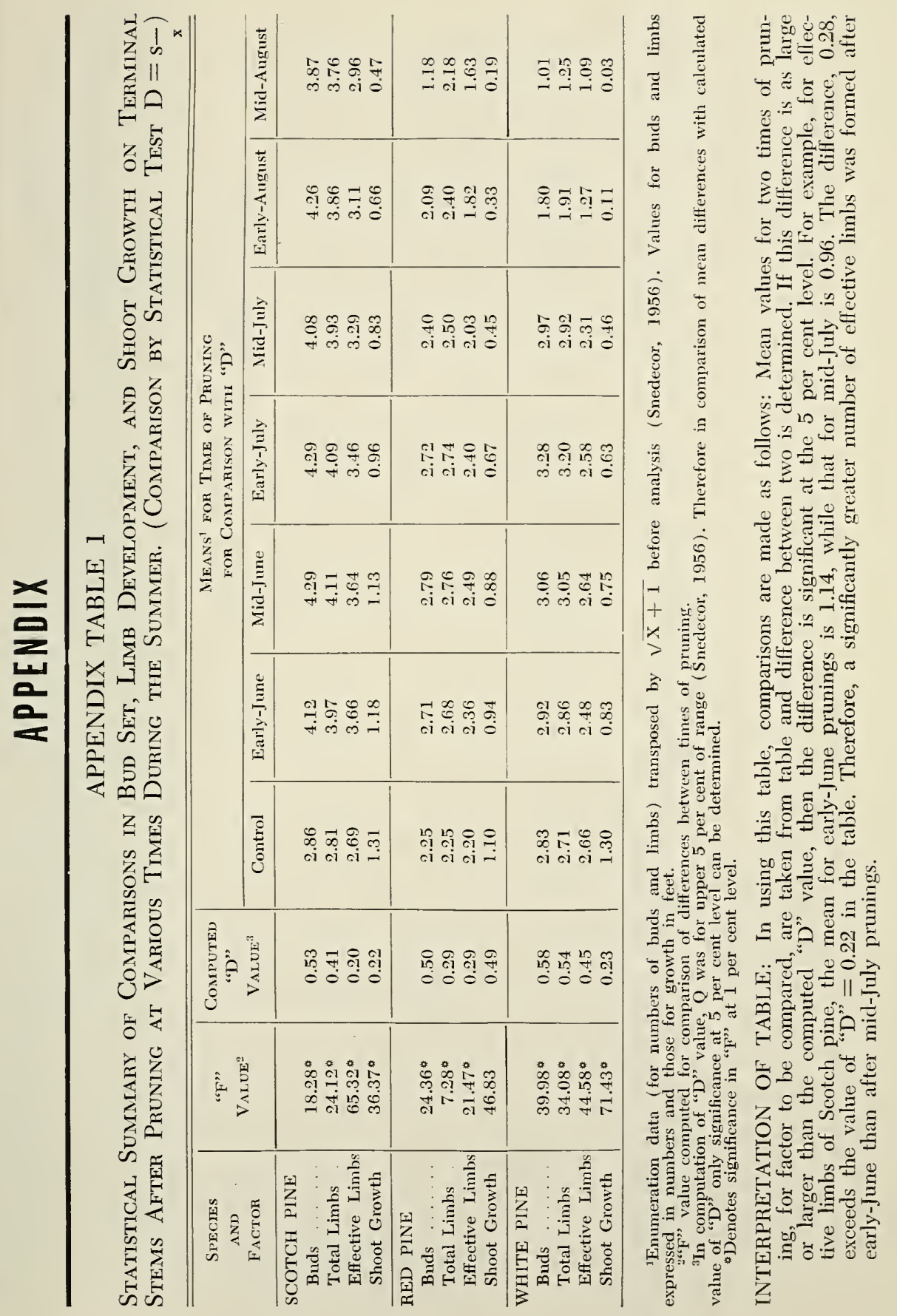




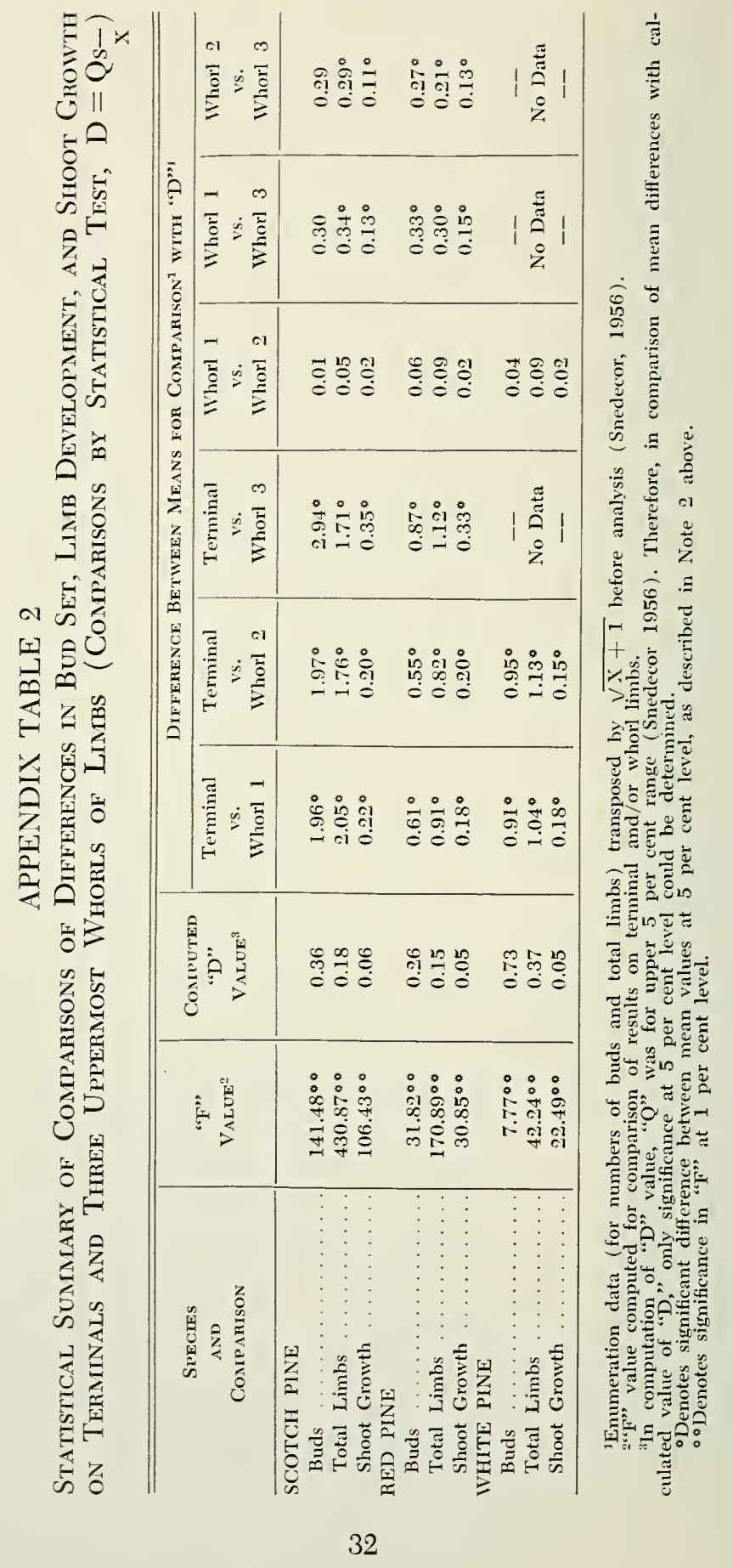


APPENDIX TABLE 3

Statistical Comparison of Results of First Prunings Versus Later Prunings

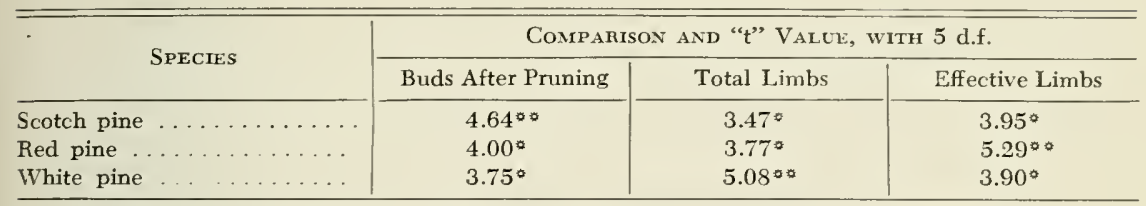

NOTE: Data transposed by $\sqrt{\mathrm{X}+1}$ before analysis (Snedecor, 1956).

- Denotes significance at 1 per cent level. 


